\title{
RELATIONSHIP BETWEEN THE PARENT'S SOCIAL ECONOMIC STATUS AND STUDENT LEARNING ENVIRONMENT WITH MATHEMATICAL LEARNING ACHIEVEMENTS IN SMP N 3 WATES
}

\author{
Arief Wibowo, Sunaryo ${ }^{b}$ \\ Program Studi Pendidikan Matematika Universitas Ahmad Dahlan \\ Jalan Ring Road Selatan, Tamanan, Banguntapan, Bantul Yogyakarta \\ bsunaryo@uad.ac.id,
}

\begin{abstract}
ABSTRAK
This study aims to analyze the relationship between parents' socioeconomic status and the learning environment of students with mathematics learning achievement for students of class VIII in the second semester of SMP N 3 Wates Kulon Progo in the 2014/2015 academic year. The population in this study were all students of class VIII Semester II as many as 75 students, consisting of 3 classes and each class consisting of 25 students. Data collection techniques used by the test method to obtain data on mathematics learning achievement, questionnaire method to obtain data on the socioeconomic status of parents and student learning environment. Item analysis uses the validity test and the reliability test. Hypothesis testing using product-moment correlation analysis and multiple linear regression analysis. The results showed that parents' socioeconomic status had a positive and significant effect on mathematics learning achievement with simple correlation analysis and the t-test obtained a correlation coefficient of 0.959 . The student learning environment has a positive and significant effect on mathematics learning achievement, with simple correlation analysis and t-test obtained correlation coefficients of 0.987 . Parents' socioeconomic status and student learning environment have a positive and significant effect on mathematics learning achievement obtained by the double determinant coefficient of 0.974 , multiple linear regression equations $\mathrm{Y}$ $=-0.000205 \mathrm{X}_{1}+0.898505 \mathrm{X}_{2}-26.981980$, this shows that the socioeconomic status of parents and learning environment towards mathematics learning achievement is $97.4 \%$. In the calculation obtained relative contributions from the socioeconomic status of parents by $0.03776 \%$ and from the student learning environment by 99.96224 . An effective contribution can be obtained from the parents' socioeconomic status by $0.03677 \%$ and from the student learning environment by $97.334112 \%$.
\end{abstract}

Keywords: Parents' Socio-Economic Status, Student Learning Environment, Mathematics Learning Achievement

\section{INTRODUCTION}

The level of livelihood of a nation is very closely related to the level of education. Education is not just about preserving culture and continuing from generation to generation but is also expected to be able to develop knowledge. Education also not only conveys skills that are already known but must be able to predict various types of skills and skills that will come as well as the right way to be mastered by students. Our society, which mostly lives in villages, generally does not pay much attention to the education of their children. They are too preoccupied with fundamental issues such as in obtaining an adequate living. Most people who live in rural areas are in very limited conditions which is a challenge for education. The causes that make the conditions are limited, among others, their land is narrow, whereas for villagers the land is the first and foremost capital, the large number of family members, difficulty in finding work, ceremonial and salvage traditions which are economically very wasteful and low education. According to Sri Rumini (1995: 60), the learning process and learning outcomes are influenced by two factors originating from within the individual who understands intelligence, attention, interest, talent, motivation, maturity, readiness, and factors originating from outside the individual who including family, school, community. The family is a factor from outside the individual and plays a role in the educational process which includes how parents educate, relationships between family members, home atmosphere, family economic situation, understanding of parents and cultural background of school factors including teaching methods, curriculum, teacher and student relations, student relations with students, student discipline, learning tools, school time, the state of the building, teaching methods, 
and homework, while the community includes friends and activities of students in the community. (Slamet, 1988: 60-71)

Of the various factors that influence learning, the family is the most important factor, because the family is the main and first place of education. The family provides the basis for the formation of morals, discipline, and independence of children. Related to the role of education in the family, there will be a difference between educating between one family and another family due to differences in the ability to educate between parents with one another.

Some of the objectives to be achieved in this study are to:

1. Analyzing the socioeconomic status of parents of students of class VIII semester II of SMP N 3 Wates, Kulon Progo in the 2014/2015 school year.

2. Analyzing the learning environment of class VIII students in the second semester of SMP N 3 Wates, Kulon Progo in the 2014/2015 school year.

3. Analyzing student achievement in class VIII semester II of SMP N 3 Wates, Kulon Progo 2014/2015 school year.

4. Analyzing the relationship between parent's socioeconomic status and student learning environment with mathematics learning achievement in class VIII semester II of SMP N 3 Wates, Kulon Progo 2014/2015 school year.

\section{METHODS}

This type of research is Ex-post facto research that is used to explain or discover how the variables in the research are interconnected or influential and the causes of the symptoms or behavior occur. (Emzir, 2013: 119) This ex-post facto research is correlational, in which the study examines the relationship between three variables namely parents' socioeconomic status variables, student learning environment variables, and mathematics learning achievement variables where these variables have occurred before the activity research. The study was conducted at SMP Negeri 3 Wates Kulon Progo class VIII Semester II Academic Year 2014/2015, in January 2015. The population in this study were all students of class VIII Semester II consisting of 3 classes, each class consisting of 25 students. If the population member is less than 100, then the sample used is the size of the existing members in the population (Suharsimi Arikunto, 1993: 103). Because the population in this study was only 75 students, this study became a population study.

1. Data Collection Method

a. Use a questionnaire method to collect data on the socioeconomic status of parents and the learning environment.

b. Use the test method to collect data about mathematics learning achievement.

2. Data Collection Techniques

Parental social status data, learning environment data, and mathematics learning achievement data were obtained using instruments that have been prepared by researchers. The first instrument to be tested was the mathematics learning achievement instrument with 25 multiple choice questions which were carried out for 60 minutes, then continued with testing the social status instrument of parents with 20 multiple choice instruments and the learning environment instrument with 25 total for 20 minutes. The implementation of this research followed mathematics lessons in each class VIII Semester II of SMP Negeri 3 Wates, Kulon Progo.

\section{RESULTS AND DISCUSSION}

\section{A. Normality test}

1. The results of the normality test for the distribution of parents' socioeconomic status variables obtained by chi-square of 16.8 with $p=0.052>0.05$, then the data is normally distributed.

2. The results of the normality test for the distribution of student learning environment variables obtained chi-square of 7.533 with p $0.582>0.05$, then the data is normally distributed. 
3. The results of the normality test distribution of mathematics learning achievement variables obtained chi-square of 12.084 with p $0.209>0.05$ then the data is normally distributed.

4. Correlation linearity test results between parents 'socioeconomic status $\left(\mathrm{X}_{1}\right)$ with mathematics learning achievement $(\mathrm{Y})$ obtained prices $\mathrm{F}_{\text {reg }} 3481,588$ with $\mathrm{p}=0,000<0.05$ thus it can be concluded that the correlation between parents' socioeconomic status with achievement learning mathematics is linear.

5. Linearity test results correlation between student learning environments $\left(\mathrm{X}_{2}\right)$ with mathematics learning achievement $(\mathrm{Y})$ obtained $\mathrm{F}_{\text {reg }}$ prices 2711,018 with $\mathrm{p}=0,000<0.05$ thus it can be concluded that the correlation between student learning environments with mathematics learning achievement is linear

6. The results of the independent test calculations indicate the value

7. $\mathrm{r}_{\mathrm{x} 1 \times 2}=0.971$ with $\mathrm{p}=0.000<0.05$ indicating the relationship between independent variables is independent

\section{Hypothesis Test I}

From the results of the analysis of the data above it is known that $r_{x 1 y}=0.959$ with $p=0,000$. Furthermore, from the value of $\mathrm{r}=0.959$, the value of $\mathrm{t}_{\text {stat }}$ is 28.77 with $\mathrm{t}_{\text {table }}=1.999(\mathrm{~N}=75, \mathrm{df}=75-2$ $=73$ ).

\section{Hypothesis Test II}

From the results of the above analysis it is known that $\mathrm{r}_{\mathrm{x} 2 \mathrm{y}}=0.987$ with $\mathrm{p}=0,000$. Furthermore, from the value of $r=0.987$, the value of $t_{\text {count }}$ is 52.07 with $t_{\text {table }}=1.999(\mathrm{~N}=75, \mathrm{dk}=75-2=73)$.

\section{Hypothesis test III}

From the results of the analysis it is known that the determinant coefficient $\left(\mathrm{R}^{2}\right)=0.974$ and $\mathrm{F}_{\text {reg }}=$ 1336.948 and the value of $\mathrm{p}=0,000$ with $\mathrm{F}_{\text {table }(5 \% ; 2: 72)}=3.12$.

\section{CONCLUSION}

1. There is a significant relationship between parents' socioeconomic status and mathematics learning achievement of VIII Semester II students in SMP N 3 Wates Kulon Progo for the 2014/2015 Academic Year.

2. There is a significant relationship between students' learning environment and mathematics learning achievement of VIII Semester II students in SMP N 3 Wates Kulon Progo for the 2014/2015 Academic Year.

3. There is a significant relationship between parent's socioeconomic status and student learning environment with mathematics learning achievement of VIII Semester II students in SMP N 3 Wates Kulon Progo for 2014/2015 Academic Year.

\section{REFERENCES}

Arifin, Z. 1991. Evaluasi Instruksional Prinsip Teknik Prosedur. Bandung: Remaja Rosdakarya

Arikunto, S. 1999. Dasar-dasar Evaluasi Pendidikan. Jakarta: Bumi Aksara

Azwar, S. 1996. Tes Prestasi Fungsi Pengemban Pengukuran Prestasi Belajar. Yogyakarta: Balai Pustaka Bernadib, I. 1988. Pendidikan Perbandingan Buku I Dasar-Dasar. Yogyakarta: Andi Offset

Crow dan crow. 1988. Psikologi Pendidikan. Jakarta: Bina Ilmu

Dakir. 1986. Dasar-dasar Psikologi. Yogyakarta: Kaliwangi Offset

Emzir. 2009. Metodologi Penelitian Pendidikan. Rajawali Pers : Jakarta

Gerungan. 1988. Psikologi Sosial. Bandung: PT. Eresco

Hadi, S. 2001. Statistik Jilid 2. Yogyakarta: Penerbit Andi

Hamalik, O. 1989. Teknik Pengukuran Evaluasi Pendidikan. Bandung: Bandar Maju

Hudoyo, H. 1988. Mengejar Belajar Matematika. Jakarta: Depdikbud

Irianto, A. 1988. Statistik Pendidikan (1). Jakarta: Depdikbud

Mahmud, P. 1988. Psikologi Pendidikan (1). Jakarta: Depdikbud

Miften dan Mifflen. 1986. Sosiologi Pendidikan. Bandung: Tarsito 
Partowisastro, K. 1983. Dinamika dalam Psikologi Pendidikan. Jakarta: Erlangga

Purwanto, N. 1987. Psikologi Pendidikan. Bandung: Remaja Karya

Ridwan. 2003. Dasar-dasar Statistik. Bandung: Alfabeta

Rukmini, Sri, dkk. Psikologi Pendidikan. Yogyakarta: UPP IKIP Yogyakarta

Rohmawati, Dina. 1996. Pengaruh Lingkungan Belajar dan Motivasi Berprestasi terhadap Prestasi Belajar Matematika siswa kelas I SMP 22 Surakarta tahun ajaran 1996/1997. Skripsi. Yogyakarta: FMIPA IKIP Yogyakarta

Slameto. 1988. Belajar dan Faktor-faktor yang mempengaruhinya. Jakarta: Bina Aksara

Soekanto, S. 1982. Sosiologi Suatu Pengantar. Jakarta: CV Rajawali

Sudjana. 1996. Teknik Analisis Regresidan Korelasi Bagi Para Peneliti. Bandung: Tarsito

Syahabuddin. 2011. Hubungan Antara Status Sosial Ekonomi dan Kemandirian Belajar terhadap Indeks Prestasi Kumulatif Mahasiswa Program Studi Pendidikan Matematika Semester III Universitas Ahmad Dahlan Tahun Ajaran 2010/2011. Skripsi. Yogyakarta: FKIP UAD Yogyakarta

Walgito, B. 1981. Bimbingan dan Penyuluhan di Sekolah. Yogyakarta: Yayasan Penerbitan Fakultas Psikologi UGM

Winkel. 1984. Psikologi Pendidikan dan Evaluasi Belajar. Jakarta: Gramedia

Sudjana. 1996. Teknik Analisis Regresi dan Korelasi bagi Para Peneliti. Bandung: Tarsito

Walgito, B. 1981. Bimbingan dan Penyuluhan di Sekolah. Yogyakarta: Yayasan Penerbitan Fakultas Psikologi. UGM

Widiastuti. 2001. Hubungan Antara Pendidikan Orang Tua dan Lingkungan Belajar dengan Prestasi Belajar Matematika Siswa Kelas I Cawu III SMA N 4 Yogyakarta tahun ajaran 2000/2001. Skripsi. Yogyakarta: FMIPA IKIP Yogyakarta

Winkel. 1984. Psikologi Pendidikan dan Evaluasi Belajar. Jakarta: Gramedia 